Article

\title{
Intensification of Continuous Biodiesel Production from Waste Cooking Oils Using Shockwave Power Reactor: Process Evaluation and Optimization through Response Surface Methodology (RSM)
}

\author{
Ahmad Abbaszadeh-Mayvan ${ }^{1}$, Barat Ghobadian ${ }^{1, *}$, Gholamhassan Najafi ${ }^{1}$ and Talal Yusaf ${ }^{2, *}$ \\ 1 Mechanic of Biosystems Engineering Department, Tarbiat Modares University, Tehran 14115-336, Iran; \\ abbaszadeh62@gmail.com (A.A.-M.); g.najafi@modares.ac.ir (G.N.) \\ 2 Office of the Pro Vice-Chancellor, Federation University, Ballarat, VIC 3350, Australia \\ * Correspondence: Ghobadib@modares.ac.ir (B.G.); t.yusaf@federation.edu.au (T.Y.); \\ Tel.: +98-912-113-5306 (B.G.); Fax: +98-214-829-2200 (B.G.)
}

Received: 27 July 2018; Accepted: 18 October 2018; Published: 21 October 2018

\begin{abstract}
This research aims to develop an optimal continuous process to produce fatty acid methyl esters (biodiesel) from waste cooking oil using a series of shockwave power reactors. Response surface methodology (RSM) based on central composite design (CCD) was used to design the experiment and to analyze five operating parameters: ratio of rotor diameter to stator diameter $(D r / D s)$, ratio of cavity diameter to rotor diameter $(D c / D r)$, ratio of cavity depth to gap between rotor and stator $(d c / \Delta r)$, rotational speed of rotor $(N)$, and Residence time $(T r)$. The optimum conditions were determined to be $D r / D s=0.73, D c / D r=0.06, d c / \Delta r=0.50,25,510.55 \mathrm{rpm}$ rotational speed of rotor, and $30.10 \mathrm{~s}$ residence times under this condition. Regarding the results, the most important parameter in shockwave power reactor (SPR) reactors was ratio of rotor diameter to stator diameter $(\mathrm{Dr} / \mathrm{Ds})$. The optimum predicted and actual FAME yield was $98.53 \%$ and $96.62 \%$, respectively, which demonstrates that RSM is a reliable method for modeling the current procedure.
\end{abstract}

Keywords: biodiesel; process intensification; response surface methodology; shockwave power reactor; waste cooking oil

\section{Introduction}

In 2017, global biofuel production increased by around 2.5\% compared to 2016, reaching 143 billion liters. Of this amount, global biodiesel production increased around $1 \%$ to 36.6 billion liters in 2017 [1]. Biodiesel is a substitute biodegradable and nontoxic fuel for compression-ignition or CI engine made from renewable energy sources, which is less damaging to the environment. Further, life cycle analysis (LCA) data for biodiesel proposes positive cumulative energy content when compared to petro diesel [2].

Nevertheless, the higher production cost of biodiesel produced from pure vegetable oils compared to diesel fuel is the main obstacle to the commercialization of biodiesel in the market [3]. Hence, it is obligatory to find the solution to minimize the production cost of biodiesel. It has been reported that between 75 and $95 \%$ of the final price of biodiesel is the cost of the raw materials including oil, alcohol, and catalysts [4,5]. Regardless of the cost of oil, the most important factors that affect the competitiveness of the biodiesel production process in order of importance are energy consumption, methanol, and catalysts [6]. Researchers pursue two main approaches in reducing the cost of biodiesel production process. The first approach is to reduce the cost of raw materials. Hence, the use of waste cooking oils (WCO) is one of the more attractive ways to reduce the raw materials 
cost [7]. Waste cooking oils as a potential renewable raw material appears to be an economically- and environmentally-applied solution for biodiesel production, and presents a number of advantages: e.g., WCO is $2-3$ cheaper than virgin edible oils [8], the reusing of WCO decreases waste treatment costs [9], and the quality of the biodiesel is the same as that produced from edible oils [10]. The second approach is the use of new technologies to reduce raw materials (alcohol and catalyst) as well as energy consumption $[10,11]$.

Currently, most commercial biodiesel is produced by the transesterification of triglycerides with methanol in stirred tank reactors (STR) using alkaline or acid homogenous catalysts [12,13]. The transesterification reaction takes place in a liquid-liquid, two-phase reaction, and the reaction kinetic is limited by poor mass transfer between two phases due to immiscibility of vegetable oils and methanol. In STR reactors, the energy input plainly comes from an impeller, but this system has some disadvantages such as high energy losses through friction, macro mixing, vortex formation, etc. The efficient contact between the triglycerides and the alcohol-catalyst mixture is critical to attain high reaction rates and economic reactor sizes.

In the last decade, research on biodiesel production processes have concentrated on the development of process-intensification technologies to enhance the mixing and mass/heat transfer between the two immiscible liquid-liquid phases (triglycerides and alcohol) in transestrification reactions. Considering these aspects, some of the process-intensification technologies that have recently been developed are static mixers [14,15], Oscillatory flow reactors [16], micro reactors [17], microwave reactors [18-20], membrane reactors [21,22], reactive distillation reactors [23,24], centrifugal contactors [25], shear reactors [12,26], ultrasonic reactors [27-29], and hydrodynamic cavitation reactors with constriction [30-32].

Among recently developed technologies, the hydrodynamic cavitation reactor is a prospective way for biodiesel production on industrial and commercial scales due to its easy scale-up characteristics [32]. There are two technologies in creating hydrodynamic cavitation; the first comprises a mechanism of cross-section with constriction, and the second is a mechanism comprising a rotor and stator called a shockwave power reactor. So far, many studies have been published on to the hydrodynamic cavitation reactor with venturi tubes or orifice plates [30-33].

However, no research has ever been carried out on the parameters that affect the performance of hydrodynamic cavitation reactors with rotor-stator mechanisms, and available information is limited to commercial advertisements [34,35].

In this study, our approach was to develop a continuous hydrodynamic cavitational reactor consisting of a series of two shockwave power reactors for the transesterification of waste cooking oil. The present work was focused on the geometric and operational parameters of shockwave power reactor that affect FAME yield in continuously-operated shockwave power reactors. The parameters studied are ratio of rotor diameter to stator diameter $(\mathrm{Dr} / \mathrm{Ds})$, ratio of cavity diameter to rotor diameter $(D c / D r)$, ratio of cavity depth to gap between rotor and stator $(d c / \Delta r)$, rotational speed of rotor $(N)$, and Residence time $(\operatorname{Tr})$. Our objectives were to better understand the relationships between the geometric and operational parameters on FAME yield, and to attain the optimum continuous transesterification conditions in a shockwave power reactor system by using statistical experimental design and response surface methodology (RSM) analysis. Finally, based on these parameters, a model was presented to predict the biodiesel production process in the developed system.

\section{Material and Method}

\subsection{Materials}

The waste cooking oil (WCO) used for biodiesel production in the present research was obtained from a local restaurant in Tehran, Iran. The fatty acid composition of WCO is presented in Table 1. Before using the collected WCO, the remains of food and water were removed using sedimentation methods at $90^{\circ} \mathrm{C}$. After preprocessing, FFA content, kinematic viscosity $\left(40{ }^{\circ} \mathrm{C}\right)$, and the molecular 
weight of the WCO was measured at $1.5 \%, 35.6 \mathrm{~mm}^{2} / \mathrm{s}$ and $876 \mathrm{~g} / \mathrm{mol}$ respectively. All chemicals, including methanol and potassium hydroxide, are of commercial grade.

Table 1. Fatty Acid composition of Waste cooking oil (wt \%).

\begin{tabular}{cccc}
\hline Fatty Acid & Formula & Structure & wt \% \\
\hline Myristic & $\mathrm{C}_{14} \mathrm{H}_{28} \mathrm{O}_{2}$ & $\mathrm{C} 14: 0$ & $4.78 \pm 0.17$ \\
Palmitic & $\mathrm{C}_{16} \mathrm{H}_{32} \mathrm{O}_{2}$ & $\mathrm{C} 16: 0$ & $30.36 \pm 0.44$ \\
Palmitoleic & $\mathrm{C}_{16} \mathrm{H}_{30} \mathrm{O}_{2}$ & $\mathrm{C} 16: 1$ & $6.46 \pm 0.22$ \\
Stearic & $\mathrm{C}_{18} \mathrm{H}_{36} \mathrm{O}_{2}$ & $\mathrm{C} 18: 0$ & $2.77 \pm 0.15$ \\
Oleic & $\mathrm{C}_{18} \mathrm{H}_{34} \mathrm{O}_{2}$ & $\mathrm{C} 18: 1$ & $32.94 \pm 0.52$ \\
Linoleic & $\mathrm{C}_{18} \mathrm{H}_{32} \mathrm{O}_{2}$ & $\mathrm{C} 18: 2$ & $21.00 \pm 0.34$ \\
Linolenic & $\mathrm{C}_{18} \mathrm{H}_{30} \mathrm{O}_{2}$ & $\mathrm{C} 18: 3$ & $0.87 \pm 0.07$ \\
Others & - & - & $0.72 \pm 0.06$ \\
\hline
\end{tabular}

\subsection{System Configurations}

Figure 1 presents a schematic diagram of the developed system for the continuous production of biodiesel using shockwave power reactors. The developed system is composed of two sets of reactors coupled together in series (Figure 1). The power generator of both reactors is provided by a $4 \mathrm{~kW}$ electromotor, jointly. It is possible to use the first reactor separately, or both reactors in series. In the series condition, output of the first reactor is fed to the second one. Every shockwave power reactor is composed of a rotor and a stator, installed in the form of two cylinders aligned towards the center (Figure 2).
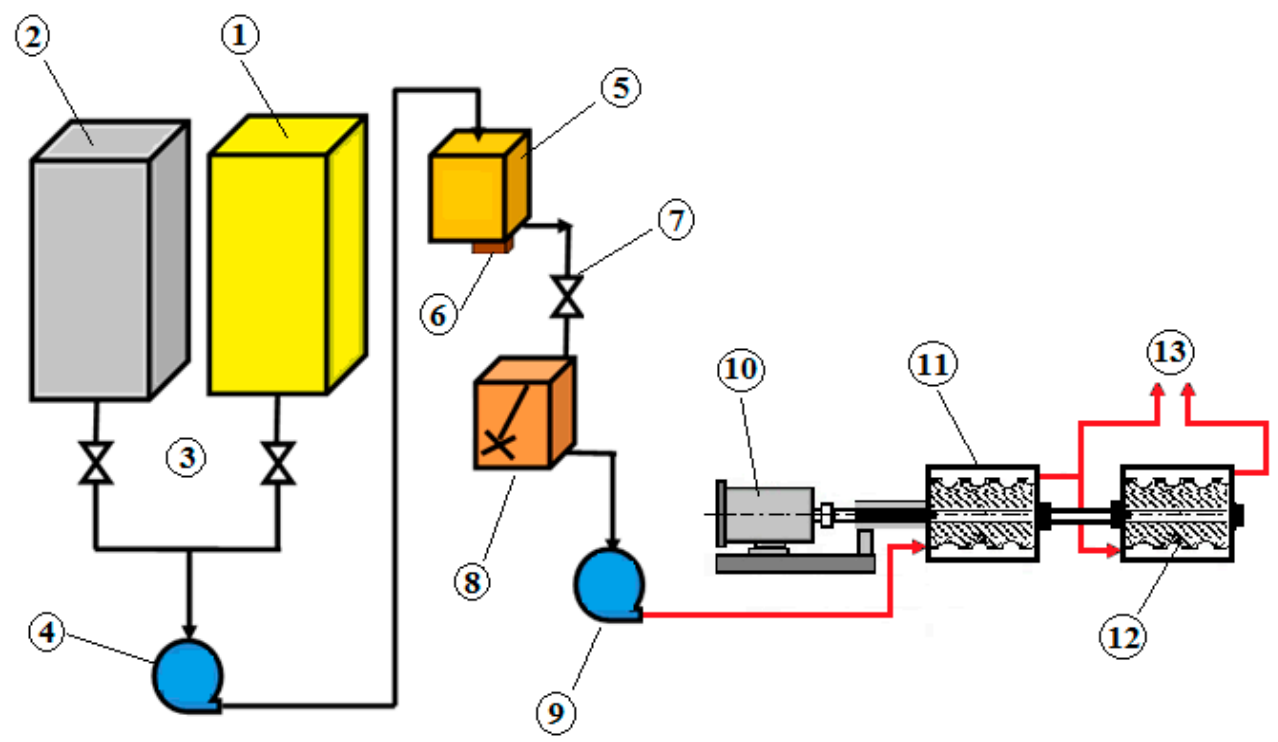

Figure 1. Schematic diagram of continuous Biodiesel production using by shockwave power reactor (SPR). 1: Oil tank, 2: Methoxide tank, 3: Valve, 4: Batching pump, 5: Batching tank, 6: Load-cell, 7: Valve, 8: Homogenizer tank, 9: Feeding pump, 10: Motor, 11: SPR reactor1, 12: SPR reactor2, 13: Separation unit.

The heart of the designed reactor in the mentioned system is a rotor rotating inside the stator at a high speed; additionally, some cavities with special geometries are machined on the perimeter of the rotor (Figure 2). The space between the rotor and the stator is the cavitation zone. While entering the reaction feed mixture (mixture of oil and alcohol) into the cavitation zone, because of geometry and arrangement of cavities machined on the rotor and spinning action of the rotor, local fluid pressure in the cavities is reduced to the fluid vapor pressure which leads to the fast formation of microscopic bubble formation in the rotor cavities away from the metal surfaces [34]. The rapid formation and 
collapse of bubbles, due to the high rotational speed of the rotor, creates shock waves which lead to intense stirring and a fast release of energy (heat). Therefore, there is no need for a heat generator source for the reaction phase of the mixture inside the reactor.
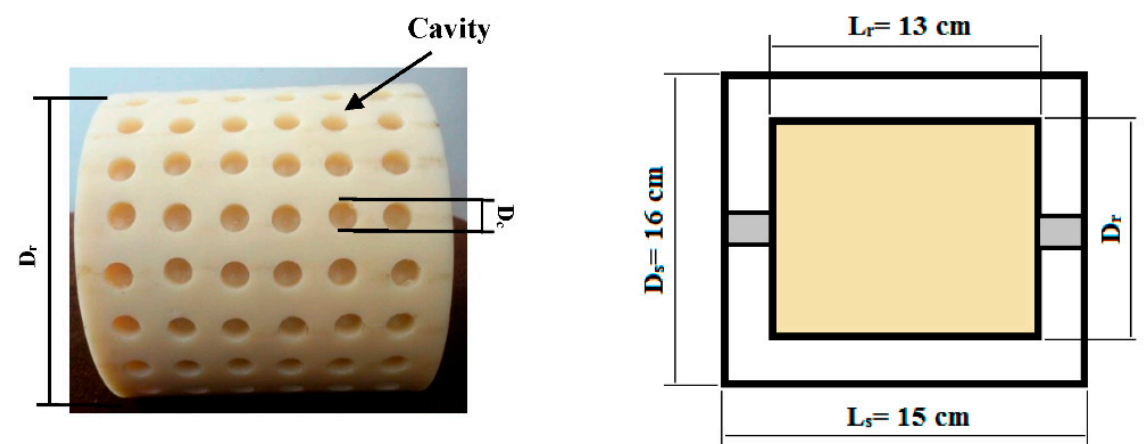

Figure 2. Dimensions of the rotor and stator in SPR reactor.

To supply the continuous reactive mixture with the exact ratio of oil to methanol, a basic mass modulation mechanism is used. Also, after modulation and before feeding to the 1 st reactor, the reactive mixture is mechanically mixed in a homogenizer vessel to form a homogenous mixture for feeding to the reactors (Figure 1). Figure 3 shows the developed system.

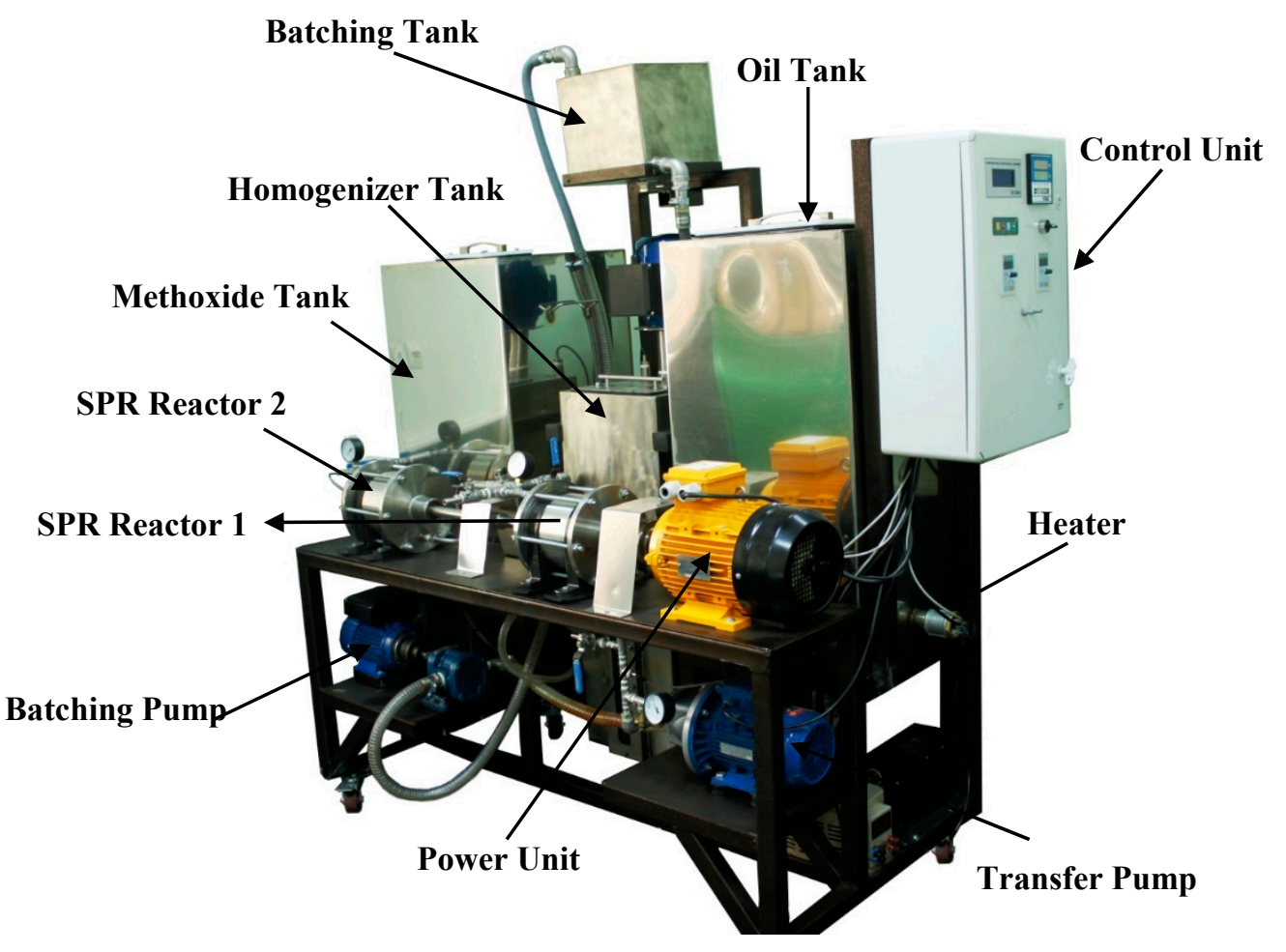

Figure 3. General view of pilot-scale unit.

\subsection{Transesterification of Waste Cooking Oil}

Gas chromatography was used to determine the fatty acid methyl ester (FAME) weight in biodiesel samples, using the European standard EN 14103 (UNE-EN 14103). The FAME weight in the reaction mixture was quantified using a gas chromatographer (Perkin Elmer Clarus 580, Shelton, CT, USA) equipped with a flame ionization detector (FID). The column was a capillary column (Agilent SelectTM Biodiesel for FAME) with dimension of $0.32 \mathrm{~mm}$ ID. $\times 30 \mathrm{~m}$ length $\times 0.25 \mu \mathrm{m}$ film thicknesses (Varian Part No.CP-9080). Helium was used as a carrier gas. The column temperature was 
kept at $60{ }^{\circ} \mathrm{C}$ for $0.5 \mathrm{~min}$, heated to $210{ }^{\circ} \mathrm{C}$ at $10^{\circ} \mathrm{C} / \mathrm{min}$, and immediately heated to $230{ }^{\circ} \mathrm{C}$ at $5{ }^{\circ} \mathrm{C} / \mathrm{min}$ and then maintained for $10 \mathrm{~min}$. Methyl heptadecanoate (C17) served as the internal standard for GC.

Firstly, the FAME of biodiesel samples was identified, and then the peak areas were utilized to quantify the FAME weight, according to Equation (1):

$$
W_{F A M E}=\frac{\left(\sum A\right)-A_{I S}}{A_{I S}} \times \frac{C_{I S} \times V_{I S} \times M}{m}
$$

where $W_{\text {FAME }}$ is fatty acid methyl ester weight $(\mathrm{mg}), \Sigma A$ total peak area, $A_{I S}$ peak area corresponding to the methyl heptadecanoate, $C_{I S}$ concentration of methyl heptadecanoate solution in heptane $(\mathrm{mg} / \mathrm{mL})$, $V_{\text {IS }}$ volume of methyl heptadecanoate solution ( $\left.\mathrm{mL}\right), \mathrm{m}$ mass of biodiesel sample (mg), and $\mathrm{M}$ Total weight of biodiesel phase in the reaction mixture $(\mathrm{mg})$. The biodiesel yield $(Y)$ was calculated according to Equation (2):

$$
Y(\%)=\frac{M W_{W C O} \times W_{F A M E}}{3 \times W_{W C O} \times M W_{F A M E}} \times 100 \%
$$

where $W_{W C O}$ is the weight of oil used, $M W_{F A M E}$ and $M W_{\text {oil }}$ are the average molecular weights of the FAME and the waste cooking oil, respectively. Factor 3 indicates that one mole of triglyceride yields three moles of FAME [36].

\subsection{Experimental Design and Statistical Analysis}

Optimization of reaction conditions for transesterification of waste cooking oil in a shockwave power reactor (SPR) was done taking Yield $(Y)$ of biodiesel production process $(E C)$ as a response to the Box-Behnken design of response surface methodology using Design-Expert 7 Software. The design was determined according to five factors: ratio of rotor diameter to stator diameter $(D r / D s)$, ratio of cavity diameter to rotor diameter $(D c / D r)$, ratio of cavity depth to gap between rotor and stator $(d c / \Delta r)$, rotational speed of rotor $(N)$, and Residence time $(\operatorname{Tr})$. The coded and encoded (actual) levels of the independent variables are given in Table 2. Forty-six experiments augmented with six center points per block were carried to evaluate the pure error; this means that regarding the suggestion of Box-Behnken design of RSM, 6 experiments of 46 experiments (zero level conditions in Table 2) must be repeated. Once the experiments are performed, the response variables were fitted to a second-order model in order to correlate the response variables to the independent variables. The general form of the quadratic polynomial equation is as follows [37]:

$$
y=\beta_{0}+\sum_{i=1}^{k} \beta_{i} X_{i}+\sum_{i=1}^{k} \beta_{i i} X_{i}^{2}+\sum_{i=1}^{k} \sum_{j=i+1}^{k} \beta_{i j} X_{i} X_{j}+\varepsilon
$$

where $y$ is the response (dependent variables), $\beta_{0}$ the constant coefficient, $\beta_{i}, \beta_{i i}$ and $\beta_{i j}$ the coefficient for the linear, quadratic and interaction effect, $x_{1}$ and $x_{j}$ the factors (independent variables), and $\varepsilon$ is the error.

Table 2. Experimental ranges and levels of the independent variables for RSM study.

\begin{tabular}{cccccc}
\hline \multicolumn{2}{c}{ Factors } & \multirow{2}{*}{ Unit } & \multicolumn{3}{c}{ Levels } \\
\cline { 5 - 6 } Actual & Coded & & $\mathbf{- 1}$ & $\mathbf{0}$ & $\mathbf{+ 1}$ \\
\hline$D r / D s$ & $\mathrm{~A}$ & - & 0.68 & 0.78 & 0.88 \\
$D c / D r$ & $\mathrm{~B}$ & - & 0.06 & 0.08 & 0.10 \\
$d c / \Delta r$ & $\mathrm{C}$ & - & 0.5 & 0.7 & 0.9 \\
$N$ & $\mathrm{D}$ & $\mathrm{rpm}$ & 2000 & 2500 & 3000 \\
$T r$ & $\mathrm{E}$ & $\mathrm{s}$ & 30 & 45 & 60 \\
\hline
\end{tabular}




\section{Results and Discussion}

\subsection{Statistical Analysis}

In this section, the relationships between responses (FAME yield) and five independent variables, i.e., ratio of rotor diameter to stator diameter $(D r / D s)$, ratio of cavity diameter to rotor diameter $(D c / D r)$, ratio of cavity depth to gap between rotor and stator $(d c / \Delta r)$, rotational speed of rotor $(N)$ and Residence time $(\operatorname{Tr})$, were studied.

Regression analysis is the general approach to fit the empirical model with the collected response variable data [38]. By using multiple regression analysis, the outcome of the experiments was correlated with the five independent factors using the quadratic polynomial equation, as in Equation (1). The coefficients of the full regression model equation and their statistical significance were determined and evaluated using Design-Expert 7 software. The predicted model in terms of coded value is:

$$
\begin{gathered}
Y(\%)=+70.50+12.04 \mathrm{~A}-2.91 \mathrm{~B}-5.02 \mathrm{C}+2.31 \mathrm{D}+1.32 \mathrm{E}-0.088(\mathrm{~A} \times \mathrm{B}) \\
+5.18(\mathrm{~A} \times \mathrm{C})-1.18(\mathrm{~A} \times \mathrm{D})-1.10(\mathrm{~A} \times \mathrm{E})-0.68(\mathrm{~B} \times \mathrm{C})+0.051(\mathrm{~B} \times \mathrm{D}) \\
-0.31(\mathrm{~B} \times \mathrm{E})+6.84(\mathrm{C} \times \mathrm{D})+0.22(\mathrm{C} \times \mathrm{E})-2.02(\mathrm{D} \times \mathrm{E})-0.16 \mathrm{~A}^{2} \\
+8.13 \mathrm{~B}^{2}+3.95 \mathrm{C}^{2}+4.29 \mathrm{D}^{2}+1.34 \mathrm{E}^{2}
\end{gathered}
$$

A plus sign in front of the terms demonstrates a synergistic effect, while a minus sign illustrates an antagonistic effect. In order to determine the efficiency and significance of the quadratic model

\begin{tabular}{|c|c|c|c|c|c|c|}
\hline Sources & Sum of Squares & DF & Mean Squares & F-Value & $p$-Value & Remark \\
\hline Model & 6089.15 & 20 & 304.46 & 9.77 & $<0.0001$ & significant \\
\hline A & 3479.17 & 1 & 3479.17 & 111.68 & $<0.0001$ & significant \\
\hline B & 203.17 & 1 & 203.17 & 6.52 & 0.0155 & significant \\
\hline $\mathrm{C}$ & 605.01 & 1 & 605.01 & 19.42 & $<0.0001$ & significant \\
\hline $\mathrm{D}$ & 135.57 & 1 & 135.57 & 4.18 & 0.0474 & significant \\
\hline $\mathrm{E}$ & 41.64 & 1 & 41.64 & 1.34 & 0.2259 & \\
\hline $\mathrm{AB}$ & 0.062 & 1 & 0.062 & $2.00 \times 10^{-3}$ & 0.9646 & \\
\hline $\mathrm{AC}$ & 214.41 & 1 & 214.41 & 6.88 & 0.0131 & significant \\
\hline $\mathrm{AD}$ & 22.44 & 1 & 22.44 & 0.72 & 0.4022 & \\
\hline $\mathrm{AE}$ & 9.65 & 1 & 9.65 & 0.31 & 0.5816 & \\
\hline $\mathrm{BC}$ & 3.70 & 1 & 3.70 & 0.12 & 0.7352 & \\
\hline $\mathrm{BD}$ & 0.021 & 1 & 0.021 & $6.736 \times 10^{-4}$ & 0.9795 & \\
\hline $\mathrm{BE}$ & 1.54 & 1 & 1.54 & 0.049 & 0.8254 & \\
\hline $\mathrm{CD}$ & 374.71 & 1 & 374.71 & 12.03 & 0.0015 & significant \\
\hline CE & 0.39 & 1 & 0.39 & 0.012 & 0.9118 & \\
\hline $\mathrm{DE}$ & 32.71 & 1 & 32.71 & 1.05 & 0.3130 & \\
\hline $\mathrm{A}^{2}$ & 0.27 & 1 & 0.27 & $8.547 \times 10^{-3}$ & 0.9269 & \\
\hline $\mathrm{B}^{2}$ & 693.20 & 1 & 693.20 & 22.25 & $<0.0001$ & significant \\
\hline$C^{2}$ & 174.99 & 1 & 174.99 & 5.62 & 0.0238 & significant \\
\hline $\mathrm{D}^{2}$ & 192.95 & 1 & 192.95 & 6.19 & 0.0180 & significant \\
\hline$E^{2}$ & 18.91 & 1 & 18.91 & 0.61 & 0.4415 & \\
\hline Residual & 1028.04 & 33 & 31.15 & & & \\
\hline Lack of Fit & 618.82 & 16 & 38.67 & 4.16 & 0.0642 & Non-significant \\
\hline Pure Error & 209.22 & 17 & 12.31 & & & \\
\hline
\end{tabular}
and the corresponding significant model terms, an analysis of variance (ANOVA) was carried out; the results are sum up in Table 3.

Table 3. ANOVA for the regression model and respective model terms.

The model F-value of 9.77 revealed that the model was highly significant $(>99.99 \%)$. This indicated that there was only a chance of $0.01 \%$ that a model F-value as large as this would occur due to noise. Therefore, the model is adequate for predicting the FAME yield within the range of the 
variables studied. The non-significant value of a lack of fit " $p$-value" that was greater than 0.05 also showed that the quadratic model was valid for the present study.

Individual-based evaluation of the model terms, as given in Table 3, showed that the linear model terms $A$ and $C$, and the interactions term $B^{2}$ were highly significant $(>99.99 \%)$, and that other terms $\mathrm{B}$ and $\mathrm{D}$ were also significant $(>95 \%)$. The interactions between variables $(\mathrm{A} \times \mathrm{C}$ and $\mathrm{C} \times \mathrm{D})$ and the second order of the terms $C^{2}$ and $D^{2}$ were significant (>95\%). The low variation coefficient value $(\mathrm{CV}=7.13 \%)$ obtained indicated a high degree of accuracy and validity of the experimental values [39].

In order to evaluate the sensitivity of the biodiesel production yield as a response for changes in independent variables, a perturbation analysis was performed. The perturbation analysis results confirmed the results of ANOVA, and showed the sensitivity of biodiesel production yield to independent variables $D r / D s, d c / \Delta r, D c / D r, N$ and $T r$ respectively (Figure 4).

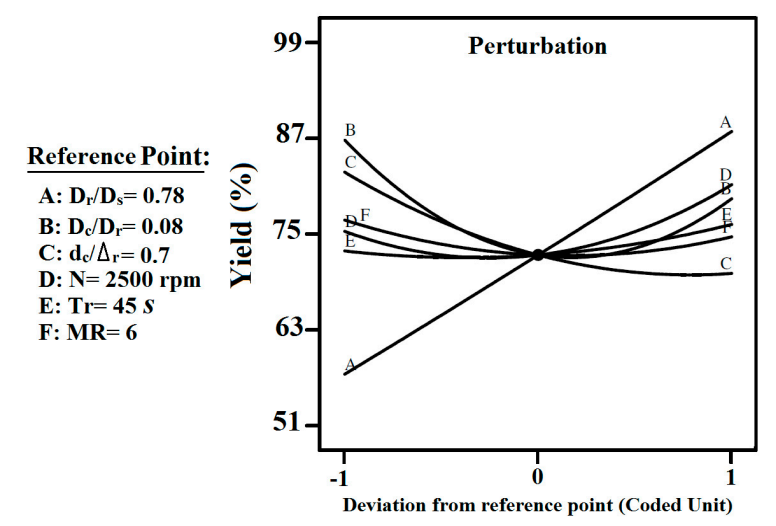

Figure 4. Perturbation of biodiesel yield versus independent variable deviation from reference point.

According to Table 3, after removing non-significant coefficients, the final predicted model in terms of actual factors for FAME yield is:

$$
\begin{gathered}
Y(\%)=+539.69-60.79\left(\frac{D_{r}}{D_{S}}\right)-3585.10\left(\frac{D_{c}}{D_{r}}\right)-529.55\left(\frac{d_{c}}{\Delta r}\right)-0.12(N) \\
+258.85\left(\frac{D_{r}}{D_{S}} \times \frac{d_{c}}{\Delta r}\right)+0.068\left(\frac{d_{c}}{\Delta r} \times N\right)+21497.67\left(\frac{D_{c}}{D_{r}}\right)^{2} \\
+93.89\left(\frac{d_{c}}{\Delta r}\right)^{2}+1.60 \times 10^{-5}\left(N^{2}\right)
\end{gathered}
$$

Figure 5 illustrated the experimental data against the predicted data using the final quadratic regression model. The linear relationships between these values indicate a strong correlation between the results obtained with experimental data and data generated with the model.

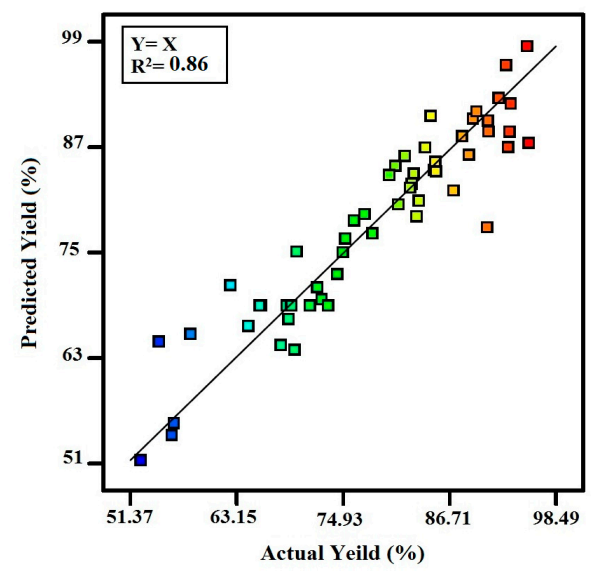

Figure 5. Predicted yield versus Experimental yield using regression model. 


\subsection{Optimization Analysis}

The optimum conditions for five variables, i.e., ratio of rotor diameter to stator diameter $(D r / D s)$, ratio of cavity diameter to rotor diameter $(D c / D r)$, ratio of cavity depth to gap between rotor and stator $(d c / \Delta r)$, rotational speed of rotor $(N)$, and residence time $(T r)$, were obtained using the numerical optimization feature of Design Expert 7 Software. The Design-Expert looks for a combination of factor levels that concurrently satisfies the criteria placed on each of the response and factors. All the factors and the response with respect to the upper and lower limit experimental regions have to satisfy the creations defined for the optimal working condition, as stated in Table 4. For this purpose, all five independent variables were configured to be within the range, while it was expected that the response would be maximized as a dependent function. These criteria led to a series of solutions predicted by the software, of which five were selected, and the first to verify the accuracy of the model was tested.

Table 4. The preset goal with constrains for all the independent factors and response in numerical optimization.

\begin{tabular}{cccccc}
\hline \multicolumn{5}{c}{ Experimental Region } \\
\hline Variable & Ultimate Goal & Lower Limit & Higher Limit & Weight & Importance \\
\hline $\operatorname{Dr} / \mathrm{Ds}(A)$ & In range & 0.68 & 0.88 & 1 & +++ \\
$\operatorname{Dc} / \operatorname{Dr}(B)$ & In range & 0.05 & 0.09 & 1 & +++ \\
$d c / \Delta r(C)$ & In range & 0.5 & 0.9 & 1 & +++ \\
$N(D)$ & In range & 1000 & 3000 & 1 & +++ \\
$\operatorname{Tr}(E)$ & In range & 30 & 90 & 1 & +++ \\
Yield $(Y)$ & Maximized & 52.53 & 96.50 & 1 & +++++ \\
\hline
\end{tabular}

+ Each plus indicates the degree of importance for variables.

The goal was set to optimize the biodiesel production yield. The optimum combination of the findings includes a ratio of rotor diameter to stator diameter $(D r / D s)$ of 0.73 , a ratio of cavity diameter to rotor diameter $(D c / D r)$ of 0.06 , a ratio of cavity depth to gap between rotor and stator $(d c / \Delta r)$ of 0.50 , a rotational speed of rotor $(N)$ of $25510.55 \mathrm{rpm}$, and a residence time $(\mathrm{Tr})$ of $30.10 \mathrm{~s}$; these parameters produced a reaction FAME yield of $98.53 \%$. To assay this optimized condition, three tests were conducted. The results showed an average FAME yield of $96.62 \%$, which is well matched with the model's prediction. There was an error of $1.97 \%$ for the FAME yield value.

\subsection{Effect of Parameters}

Regarding the sum of squares of rotor diameter to stator diameter (Dr/Ds) shown in Table 3, the variance analysis shows that about $48.88 \%$ of the data variations are related to this variable, emphasizing that it has a crucial role in determining the biodiesel yield. In addition, the high and positive coefficient of $(D r / D s)$ in the regression model (Equation (2)) shows that an increase of rotor diameter in the range of this study would lead to an increase in the biodiesel yield. An investigation of interaction of $(D r / D s)$ with other independent variables shows that an increase of the $(D r / D s)$ ratio in the interaction condition would lead to an increase in FAME conversion. (Dr/Ds) also shows the interval of rotator and stator inside the reactor to be inversely proportional. In other words, in higher ratios, the interval of the rotor and stator would decrease. So, we can conclude that a decrease in the rotor-stator interval (in experimental range) would lead to an intensifying of the transestrification reaction. The arrangement of machined cavities on the rotors creates an interval between the rotor and stator while the rotor is in motion. Assuming that at any time of process a specific volume of reactive feed fluid is placed on the cavities, a sudden increase in the gap between the spinning rotor and stator causes a severe pressure drop inside the cavities, as it does doe the vapor pressure of the reactive feed. Such a pressure drop leads to the formation of cavities inside this specific volume of the fluid in the form of bubbles, which is filled by phase-changed fluid (vapor). 
By continuous rotation of the rotor, when the volume of the fluid reaches to the smooth surface of rotor, the rotor-stator interval would suddenly decrease, leading to a severe pressure increase in that area, causing the collapse of formed bubbles and a release of the inside gases. The collapse of bubbles and release of gases also creates a shock wave in the gap between the rotor-stator. The created shock has a specific diffusion depth in the reactive mixture between the rotator and stator. Hence, regarding the continuity of the production process, a decrease of the rotator-stator interval causes a lower portion (thinner layer) of reactive mixture to be located in the area of cavitation and released energy, which increases the rate of the transesterification reaction of the feed, and as a result increases, the FAME yield.

The ratio of the cavity dimension to rotor dimension $(D c / D r)$ also shows the diameter of the machined cavities on the rotor's perimeter in comparison with the rotor dimension. So, higher ratios in the same rotor dimensions show an increase in the cavity diameter. Regarding the negative coefficient of $D c / D r(B)$, in the regression Equation (2), it can be concluded that cavities with smaller diameters would lead to an increase of biodiesel yield, because by reducing the cavity diameter, it is possible to machine more cavities, either along the rotor length or periphery. An increase of cavity numbers means an increase in the bubble production and collapse cycle, leading to higher intensity in the transesterification reaction.

Results of ANOVA have shown that the rations of rotor diameter to stator diameter (Dr/Ds) and cavity depth to the interval of rotor-stator $(d c / \Delta r)$ on the biodiesel yield are statistically significant. As depicted in Figure 6, by increasing the ratio of $(D r / D s)$ to ratio of cavity depth to the rotor-stator interval $(d c / \Delta r)$ in all levels, the biodiesel yield was raised. In the case of rotors with larger diameters $(D r / D s=0.88)$, the difference of plots of different levels disappears. This can be attributed to the equilibrium and reversible nature of transesterification reaction.

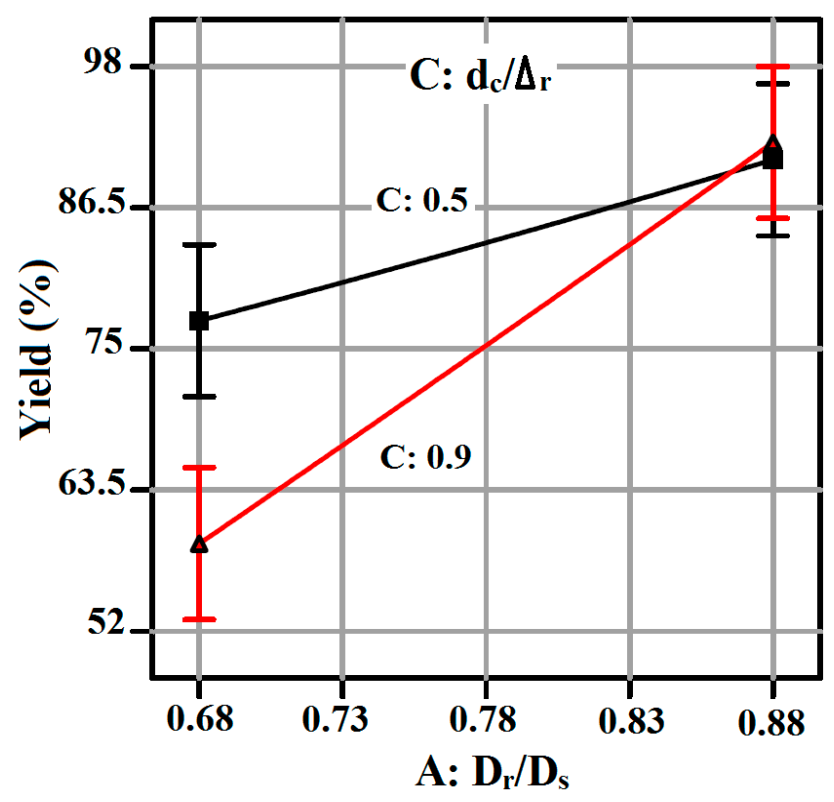

Figure 6. Interaction of rotor diameter to stator diameter $(D r / D s)$ and ratio of cavity depth to the interval of rotor-stator $(d c / \Delta r)$ on the biodiesel yield.

While operating both reactors in series, the reactive mixture feed spends more time inside the reactor environments. So, in the cavities with higher depth (less intensification of the reaction), there is a chance to improve the reaction for the conversion of fatty acids to fatty acid methyl ester (biodiesel), so that the biodiesel conversion becomes similar to that which occurs within the shallower cavities.

On the other hand, it can be seen that in all ratios of $(D r / D s)$, rotors equipped by shallower cavities have better biodiesel yields. The negative coefficient of the linear term $(-5.02)$ related to 
the $d c / \Delta r$ parameters on regression model (2) also shows the reverse effect of this variable on yield. Experimental observations also prove this point. At the time of replacement and installation of new rotors, around the edges, especially in the upper part of the cavities, some signs of corrosion and melting were observed. Therefore, it can be concluded that the cavitation phenomenon was more intense in such areas.

A plus sign in front of the linear term of rotational speed variable in regression model (Equation (2)) indicates a synergistic effect of this variable on FAME yield. The rotational speed, in addition to parameters like diameter of rotor and diameter of the cavities machined on the rotor, are among the main factors determining the degree of occurrence of the cavitation phenomenon inside the reactors at a specific time. Hence, intensification of the transesterification reaction (via increase of mass and heat transfer) by increasing the rotational speed in the same diameter of the cavity and rotor is reasonable. Results of ANOVA have demonstrated that the interaction of two variables, i.e., rotational speed $(N)$ and the ratio of cavity depth to the rotor-stator interval $(d c / \Delta r)$, has a significant effect on FAME yield $(<0.05)$. Figure 7 illustrates the interaction effects of rotational speed $(N)$ and the ratio of cavity depth to the rotor-stator interval $(d c / \Delta r)$.

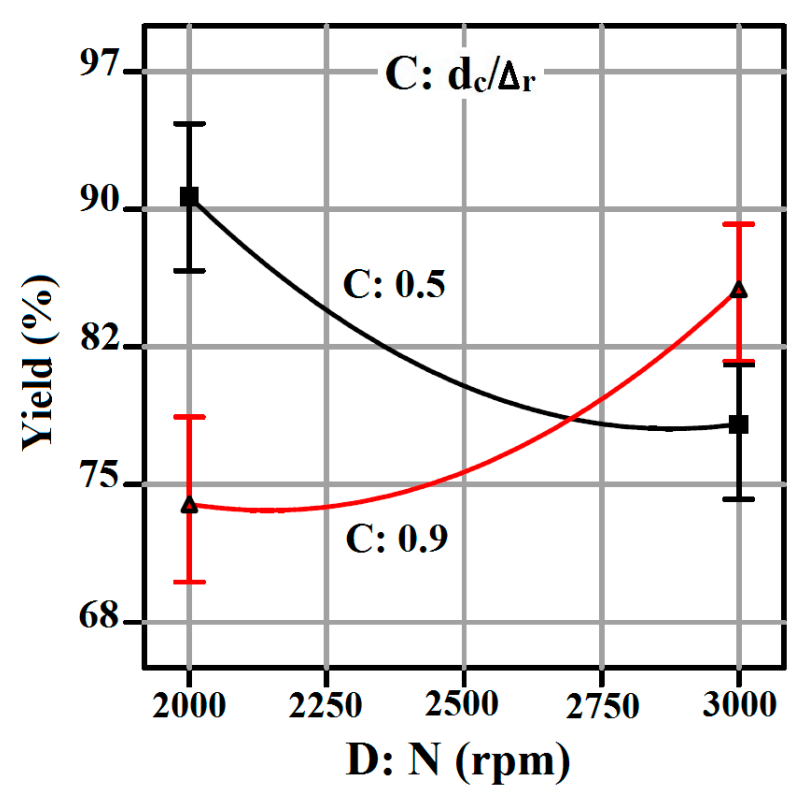

Figure 7. Interaction of rotational speed of rotor $(N)$ and ratio of cavity depth to the interval of rotor-stator $(d c / \Delta r)$ on the biodiesel yield.

It is observed that the maximum FAME yield occurred in the condition of lower rotational speed (2000 rpm) and shallower cavities $(d c / \Delta r=0.5)$. In addition, regarding the restriction of the upper limit of FAME yield in the transesterification reaction, lower $d c / \Delta r$ (higher intensification) and lower rotational speed (lower intensification) had a positive effect on the FAME yield (reaction improvement in desirable side), while in the case of lower $d c / \Delta r$ (higher intensification) and higher rotational speed (higher intensification), a negative effect on FAME yield was observed (reaction improvement in undesirable side).

In the continuous process, investigation of the optimum residence time of the reaction is crucial for the biodiesel conversion efficiency. Hence, in this study, 3 levels of residence time, i.e., 30, 45 and $60 \mathrm{~s}$, were examined. Regarding the reactors with different rotor dimensions, various flow rates of the reactive feed were considered to keep the reaction residence time. Statistical investigations have demonstrated that the linear term of residence time did not have a significant effect on the biodiesel yield (Table 3). However, regarding the positive coefficient of the linear term of the reaction residence time (+1.32) in the regression equation (Equation (2)), it can be inferred that a greter biodiesel yield was achieved with higher residence times. 


\section{Conclusions}

The present study showed that two shockwave power reactors with series arrangement could be used as an efficient technology for the intensification of biodiesel production from waste cooking oils. The response surface methodology based on a central composite design (CCD) could effectively determine the optimal values of geometrical and operational parameters corresponding to maximum FAME yield. The optimized conditions found by the RSM method were: 0.73 ratio of rotor diameter to stator diameter $(D r / D s), 0.06$ ratio of cavity diameter to rotor diameter $(D c / D r), 0.50$ ratio of cavity depth to gap between rotor and stator $(d c / \Delta r), 25,510.6 \mathrm{rpm}$ rotating speed of rotor $(N)$, and $30.10 \mathrm{~s}$ residence time ( $\operatorname{Tr}$ ); a 96.62\% FAME yield was determined under this condition. The most important parameter for the SPR reactor was ratio of rotor diameter to stator diameter (Dr/Ds).

Author Contributions: Conceptualization, A.A.-M. and B.G..; Funding acquisition, B.G.; Methodology, A.A.-M., B.G. and G.N.; Formal Analysis, A.A.-M.; Investigation, A.A.-M.; Resources, B.G. and G.N.; Project administration, B.G.; Supervision, B.G.; Writing-Original Draft Preparation, A.A.-M.; Writing-review \& editing, T.Y.

Funding: The authors are grateful to the Tarbiat Modares University (http:/ / www.modares.ac.ir) for financial supports given under IG/39705 grant for renewable Energies of Modares research group.

Acknowledgments: The authors gratefully acknowledge the Bioenergy research center from Tarbiat Modares University for their financial support.

Conflicts of Interest: The authors declare no conflict of interest.

\section{References}

1. Renewables 2018 Global Status Report. Available online: http://www.ren21.net/gsr (accessed on 20 August 2018).

2. Vonortas, A.; Papayannakos, N. Comparative analysis of biodiesel versus green diesel. Rev. Energy Environ. 2014, 3, 3-23. [CrossRef]

3. Chongkhong, S.; Tonguara, C.; Chetpattananondh, P.; Bunyaka, C. Biodiesel production by esterification of palm fatty acid distillate. Biomass Bioenergy 2007, 31, 563-568. [CrossRef]

4. Yuste, A.J.; Dorado, M.P. A neural network approach to simulate biodiesel production from waste olive oil. Energy Fuels 2006, 20, 399-402. [CrossRef]

5. Hasheminejad, M.; Tabatabaei, M.; Mansourpanah, Y.; Khatamifar, M.; Javani, A. Upstream and downstream strategies to economize biodiesel production. Bioresour. Technol. 2010, 102, 461-468. [CrossRef] [PubMed]

6. Cintas, P.; Mantegna, S.; Calcio Gaudino, E.; Cravotto, G. A new pilot flow reactor for high-intensity ultrasound irradiation. Application to the synthesis of biodiesel. Ultrason. Sonochem. 2010, 17, 985-989. [CrossRef] [PubMed]

7. Avinash, A.; Murugesan, A. Economic analysis of biodiesel production from waste cooking oil. Energy Sour. Part B Econ. Plan. Policy 2017, 12, 890-894. [CrossRef]

8. Zhang, Y.; Dubé, M.A.; McLean, D.D.; Kates, M. Biodiesel production from waste cooking oil: 2. Economic assessment and sensitivity analysis. Bioresour. Technol. 2003, 90, 229-240. [CrossRef]

9. Banerjee, A.; Chakraborty, R. Parametric sensitivity in transesterification of waste cooking oil for biodiesel production-A review. Resour. Conserv. Recycl. 2009, 53, 490-497. [CrossRef]

10. Chhetri, A.B.; Watts, K.C.; Islam, M.R. Waste Cooking Oil as an Alternate Feedstock for Biodiesel Production. Energies 2008, 1, 3-18. [CrossRef]

11. Moecke, E.H.S.; Feller, R.; Santos, H.A.D.; Machado, M.D.M.; Cubas, A.L.V.; Dutra, A.R.D.A.; Santos, L.L.V.; Soares, S.R. Biodiesel production from waste cooking oil for use as fuel in artisanal fishing boats: Integrating environmental, economic. J. Clean. Prod. 2016, 135, 679-688. [CrossRef]

12. Qiu, Z. Intensification of Liquid-Liquid Contacting Processes. Ph.D Thesis, Department of Chemical and Petroleum Engineering, University of Kansas, Lawrence, KS, USA, 2010.

13. Abbaszadeh, A.; Ghobadian, B.; Omidkhah, M.R.; Najafi, G. Current biodiesel production technologies: A comparative review. Energy Convers. Manag. 2012, 63, 138-148. [CrossRef]

14. Sungwornpatansakul, P.; Hiroi, J.; Nigahara, Y.; Jayasinghe, T.K.; Yoshikawa, K. Enhancement of biodiesel production reaction employing the static mixing. Fuel Process. Technol. 2013, 116, 1-8. [CrossRef] 
15. Somnuk, K.; Prasit, T.; Prateepchaikul, G. Effects of mixing technologies on continuous methyl ester production: Comparison of using plug flow, static mixer, and ultrasound clamp. Energy Convers. Manag. 2017, 140, 91-97. [CrossRef]

16. Suryanto; Utomo, W.B.; Marwan. Novel Oscillatory Flow Reactor to Improve Biodiesel Production Continuous System. Int. J. Sci. Res. 2015, 4, 103-106.

17. Azam, N.A.M.; Uemura, Y.; Kusakabe, K.; Bustam, M.A. Biodiesel Production from Palm Oil Using Micro Tube Reactors: Effects of Catalyst Concentration and Residence Time. Procedia Eng. 2016, 148, 354-360. [CrossRef]

18. Cancela, A.; Maceiras, R.; Urrejola, S.; Sanchez, A. Microwave-Assisted Transesterification of Macroalgae. Energies 2012, 5, 862-871. [CrossRef]

19. Choedkiatsakul, I.; Ngaosuwan, K.; Assabumrungrat, S.; Mantegna, S.; Cravotto, G. Biodiesel production in a novel continuous flow microwave reactor. Renew. Energy 2015, 83, 25-29. [CrossRef]

20. Lertsathapornsuk, V.; Pairintrab, R.; Aryusukb, K.; Krisnangkurab, K. Microwave assisted in continuous biodiesel production from waste frying palm oil and its performance in a $100 \mathrm{~kW}$ diesel generator. Fuel Process. Technol. 2008, 89, 1330-1336. [CrossRef]

21. Dube, M.A.; Tremblay, A.Y.; Liu, J. Biodiesel production using a membrane reactor. Bioresour. Technol. 2007, 98, 639-647. [CrossRef] [PubMed]

22. Atadashi, I.M.; Aroua, M.K.; Abdul Aziz, A.R.; Sulaiman, N.M.N. Membrane biodiesel production and refining technology: A critical review. Renew. Sust. Energy Rev 2011, 15, 5051-5062. [CrossRef]

23. Pradana, Y.S.; Hidayat, A.; Prasetya, A.; Budiman, A. Biodiesel production in a reactive distillation column catalyzed by heterogeneous potassium catalyst. Energy Procedia 2017, 143, 742-747. [CrossRef]

24. Simasatitkul, L.; Siricharnsakunchai, P.; Patcharavorachot, Y.; Assabumrungrat, S.; Arpornwichanop, S. Reactive distillation for biodiesel production from soybean oil. Korean J. Chem. Eng. 2011, 28, $649-655$. [CrossRef]

25. Ilmi, M.; Kloekhorst, A.; Winkelman, J.G.M.; Euverink, G.J.W.; Hidayat, C.; Heeres, H.J. Process intensification of catalytic liquid-liquid solid processes: Continuous biodiesel production using an immobilized lipase in a centrifugal contactor separator. Chem. Eng. J. 2017, 321, 76-85. [CrossRef]

26. Silva, N.D.L.D.; Garnica, J.A.G.; Batistella, C.B.; Maciel, M.R.W.; Filho, R.M. Use of experimental design to investigate biodiesel production by multiple-stage Ultra-Shear reactor. Bioresour. Technol. 2011, 102, 2672-2677. [CrossRef] [PubMed]

27. Mostafaei, M.; Ghobadian, B.; Barzegar, M.; Banakar, A. Optimization of ultrasonic assisted continuous production of biodiesel using response surface methodology. Ultrason. Sonochem. 2015, 27, 54-61. [CrossRef] [PubMed]

28. Hingu, S.M.; Gogate, R.; Rathod, V.K. Synthesis of biodiesel from waste cooking oil using sonochemical reactors. Ultrason. Sonochem. 2010, 17, 827-832. [CrossRef] [PubMed]

29. Chang, C.; Teng, S.; Yuan, M.; Ji, D.; Chang, C.; Chen, Y.; Shie, J.; Ho, C.; Tian, S.; Andrade-Tacca, C.A.; et al. Esterification of Jatropha Oil with Isopropanol via Ultrasonic Irradiation. Energies 2018, 11, 1456. [CrossRef]

30. Ghayal, D.; Pandit, A.B.; Rathod, V.K. Optimization of biodiesel production in a hydrodynamic cavitation reactor using used frying oil. Ultrasonics Sonochem. 2013, 20, 322-328. [CrossRef] [PubMed]

31. Maddikeri, G.; Gogate, P.R.; Pandit, A. Intensified synthesis of biodiesel using hydrodynamic cavitation reactors based on the interesterification of waste cooking oil. Fuel 2014, 137, 285-292. [CrossRef]

32. Pal, A.; Verma, A.; Kachhwaha, S.S.; Maji, S. Biodiesel production through hydrodynamic cavitation and performance testing. Renew. Energy 2010, 35, 619-624. [CrossRef]

33. Gogate, P.R. Cavitational reactors for process intensification of chemical processing applications: A critical review. Chem. Eng. Process. 2008, 47, 515-527. [CrossRef]

34. Hydro Dynamics, Inc. 2015. Available online: http://hydrodynamics.com (accessed on 14 March 2017).

35. Mancosky, D.G.; Armstead, D.A.; McGurk, T.; Hopkins, G.; Hudson, K. The Use of a Controlled Cavitation Reactor for Bio-Diesel Production. In Proceedings of the AIChE Spring Meeting and Global Congress on Process Safety, Houston, TX, USA, 24 April 2007.

36. Thanh, L.T.; Okitsu, K.; Sadanaga, Y.; Takenaka, N.; Maeda, Y.; Bandow, H. A two-step continuous ultrasound assisted production of biodiesel fuel from waste cooking oils: A practical and economical approach to produce high quality biodiesel fuel. Bioresour. Technol. 2010, 101, 5394-5401. [CrossRef] [PubMed] 
37. Tiwari, A.K.; Kumar, A.; Raheman, H. Biodiesel production from jatropha oil (Jatropha curcas) with high free fatty acids: An optimized process. Biomass Bioenergy 2007, 31, 569-575. [CrossRef]

38. Montgomery, D.C. Design and Analysis of Experiments, 5th ed.; John Wiley \& Sons: New Work, NY, USA, 2000; ISBN 9780471316497.

39. Ryan, T.P. Modern Experimental Design; John Wiley \& Sons: Hoboken, NJ, USA, 2007; ISBN 978-0-471-21077-1.

(C) (1)

(c) 2018 by the authors. Licensee MDPI, Basel, Switzerland. This article is an open access article distributed under the terms and conditions of the Creative Commons Attribution (CC BY) license (http:/ / creativecommons.org/licenses/by/4.0/). 